\title{
The Eurasian ice sheet reinforces the East Asian summer monsoon during the interglacial 500000 years ago
}

\author{
Qiuzhen Yin, A. Berger, E. Driesschaert, H. Goosse, M. F. Loutre, and M. Crucifix \\ Catholic University of Louvain, Institute of Astronomy and Geophysics G., Lemaître, Chemin du Cyclotron 2, 1348 \\ Louvain-la-Neuve, Belgium
}

Received: 5 November 2007 - Published in Clim. Past Discuss.: 26 November 2007

Revised: 25 April 2008 - Accepted: 25 April 2008 - Published: 23 May 2008

\begin{abstract}
Deep-sea and ice-core records show that interglacial periods were overall less "warm" before about 420000 years ago than after, with relatively higher ice volume and lower greenhouse gases concentration. This is particularly the case for the interglacial Marine Isotope Stage 13 which occurred about 500000 years ago. However, by contrast, the loess and other proxy records from China suggest an exceptionally active East Asian summer monsoon during this interglacial. A three-dimension Earth system Model of Intermediate complexity was used to understand this seeming paradox. The astronomical forcing and the remnant ice sheets present in Eurasia and North America were taken into account in a series of sensitivity experiments. Expectedly, the seasonal contrast is larger and the East Asian summer monsoon is reinforced compared to Pre-Industrial time when Northern Hemisphere summer is at perihelion. Surprisingly, the presence of the Eurasian ice sheet was found to reinforce monsoon, too, through a south-eastwards perturbation planetary wave. The trajectory of this wave is influenced by the Tibetan plateau.
\end{abstract}

\section{Introduction}

Most of the $\delta^{18} \mathrm{O}$ records in deep-sea sediments show a significantly reduced amplitude of the ice volume variations before Marine Isotope Stage (MIS) 11, about $400 \mathrm{ka}$ ago, with less warm (cooler) interglacials and generally less cold glacials (Imbrie et al., 1984; Bassinot et al., 1994; Tiedemann et al., 1994; Shackleton, 2000; Lisiecki and Raymo, 2005). The deuterium temperature record in the Antarctic ice cores shows the same features (EPICA, 2004; Jouzel et al., 2007). The amplitude of the variations of the greenhouse

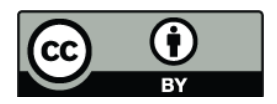

Correspondence to: Qiuzhen Yin (yin@astr.ucl.ac.be) gases (GHG) concentration is also reduced before MIS-11 (Siegenthaler et al., 2005; Spahni et al., 2005). Explaining such a reduction in the amplitude of climate and GHG concentration variations before $420 \mathrm{kaBP}$ is certainly one of the exciting challenges for the palaeoclimate community over the next years. As this phenomenon is present in both deep-sea and ice cores, it is tempting to conclude that before $420 \mathrm{ka}$ BP climate was overall less varying between glacial and interglacial periods and the interglacials were cooler. In this context, traces of exceptionally strong monsoon activity in East Asia at MIS-13 come as a surprise. This indications come from the loess in northern China (e.g. Kukla et al., 1990; Guo et al., 1998), the sedimentary core in the eastern Tibetan Plateau (Chen et al., 1999) and the palaeosols in southern China (Yin and Guo, 2006). All record an unusually warm and wet climate during MIS-13, indicating an extremely strong East Asian Summer Monsoon (EASM), actually the strongest ever recorded over the whole Quaternary. During the same interglacial, unusually strong African and Indian monsoons are recorded in the sediments of the equatorial Indian Ocean (Bassinot et al., 1994) and of the Mediterranean Sea (Rossignol-Strick et al., 1998). Other temperature and precipitation extremes are also recorded in sediment cores of the equatorial Atlantic, the Pacific, the subtropical South Atlantic Ocean (e.g. Harris and Mix, 1999; Schmieder et al., 2000; Gingele and Schmieder, 2001; Wang et al., 2004) and in the Lake Baikal of Siberia (Prokopenko et al., 2002) (see also the review by Yin and Guo, 2008).

It is known from climate model simulations and proxy data that monsoon activity is influenced by climate precession: precipitation is generally increased when summer occurs at perihelion, which causes higher daily insolation (e.g. Kutzbach and Guetter, 1984; Prell and Kutzbach, 1987; Joussaume, 1999; Braconnot, 2007). On the other hand, other simulations (e.g. Yanase and Abe-Ouchi, 2007) show reduced EASM at the Last Glacial Maximum (LGM), which suggest that EASM is weak when the Northern Hemisphere

Published by Copernicus Publications on behalf of the European Geosciences Union. 
$(\mathrm{NH})$ is cold overall. From the latter, one could expect a moderate monsoon at MIS-13 because this interglacial was not as warm and deglaciated as the more recent interglacials, although Masson et al. (2000) suggested that glacial conditions at MIS-6.5 do not prevent high insolation to produce a strong monsoon.

This seeming paradox of a strong EASM occurring during the relatively "cool" MIS-13 is addressed here by means of simulations with the climate model of intermediate complexity LOVECLIM (described in Sect. 2). Sensitivity experiments were designed to study the model response to the astronomical and ice sheets forcings representative of 495, 506 and $529 \mathrm{ka} \mathrm{BP}$ (described in Sect. 3). Section 4 focuses more on the results for 495 and $506 \mathrm{kaBP}$ (MIS-13.1), with an emphasis on the role of the Eurasian ice sheet, and Sect. 5 discusses the results for $529 \mathrm{ka}$ BP (MIS-13.3) before drawing conclusions.

Note that the Wang et al. (2003) definition of the East Asia subtropical monsoon area is adopted throughout this article $\left(105-140^{\circ} \mathrm{E}, 22.5-45^{\circ} \mathrm{N}\right)$.

\section{The model}

The model used is the three-dimension Earth system Model of Intermediate Complexity LOVECLIM1.1 (Driesschaert et al., 2007). LOVECLIM consists of five components representing the atmosphere (ECBilt), the ocean-sea ice (CLIO), the terrestrial biosphere (VECODE), the oceanic carbon cycle (LOCH) and the Greenland and Antarctic ice sheets (AGISM). The version used here takes into account the interactions between the atmosphere (ECBilt), the ocean-sea ice (CLIO) and the terrestrial biosphere (VECODE). Ice sheets are prescribed, and their impact on the atmosphere is taken into account through albedo and topography. ECBilt is a quasi-geostrophic atmospheric model with $3 \mathrm{lev}$ els and a T21 horizontal resolution (Opsteegh et al., 1998). The influence of topography on atmospheric dynamics is included through the boundary condition on the vertical velocity (see Eq. 5 of Opsteegh et al., 1998). Timmerman (2004) showed that the sensitivity of ECBILT to small topographic changes is overall realistic. CLIO is a primitiveequation, free-surface ocean general circulation model coupled to a thermodynamic-dynamic sea ice model (Goosse and Fichefet, 1999). Its horizontal resolution is $3^{\circ} \times 3^{\circ}$, and there are 20 levels on the vertical in the ocean. VECODE is a reduced-form model of vegetation dynamics and of the terrestrial carbon cycle (Brovkin et al., 2002). It simulates the dynamics of two plant functional types (trees and grassland) at the same resolution as that of ECBilt. Previous ECBilt-CLIO-VECODE model versions have been used in a large number of climate studies (http://www.knmi. $\mathrm{nl} /$ onderzk/CKO/ecbilt-papers.html), including the last interglacial (Duplessy et al., 2007) and Last Glacial Maximum (LGM) climate (Timmermann et al., 2004; Roche et al., 2007). The model has also taken part in several model intercomparison projects for the simulation of past climate (e.g. Braconnot et al., 2007). More information about the LOVECLIM model itself and a complete list of references is available at http://www.astr.ucl.ac.be/index.php? page $=$ LOVECLIM40Description. LOVECLIM had already been used in many sensitivity experiments and the control climate has been shown and discussed in, for example, Renssen et al. (2002).

LOVECLIM admittedly exhibits serious weaknesses in its simulation of Asian precipitation. In particular, the summer precipitation is clearly underestimated and the low-level geopotential ridge over the North Pacific is shifted northward 10 degrees in latitude compared to observations (Fig. 1). These weaknesses are most likely caused by insufficient spatial resolution and simplified convective physics. As a consequence, quantitative estimates of the effects of astronomical parameters and ice sheets on East Asian precipitation should not be interpreted too rigidly. Yet, we believe that LOVECLIM has proved to be a reasonably appropriate tool to identify teleconnections. Along with its computing efficiency, this justifies using this model for a first qualitative assessment of the connections between ice sheets and sub-tropical dynamics by means of a series of sensitivity experiments.

\section{Climate forcings and experiment design}

According to the deep-sea $\delta^{18} \mathrm{O}$ records, MIS-13 is characterized by 3 peaks: 13.11, 13.13 and 13.3 (Imbrie et al., 1984; Bassinot et al., 1994; Tiedemann et al., 1994; Shackleton, 2000; Lisiecki and Raymo, 2005). They occur respectively at about 482,501 and $524 \mathrm{ka}$ BP with dating uncertainty of the order of a few thousands of years. For example, MIS13.3 was assumed to peak at $524 \mathrm{ka} \mathrm{BP}$ as a compromise between the records of Lisiecki and Raymo (2005), Tiedemann et al. (1994), Bassinot et al. (1994), Shackleton (2000) and SPECMAP (Imbrie et al., 1984, provided their label 14.0 is changed into 13.3).

In our experiments, the model is forced by (i) the latitudinal and seasonal distributions of the energy received from the Sun and computed from the appropriate astronomical elements (Berger, 1978), (ii) the GHG concentration retrieved from the Dome $\mathrm{C}$ ice core in Antarctica and (iii) the ice sheets assumed to exist during this interglacial. All the climatic features of the MIS-13 simulations will be compared to the simulated Pre-Industrial (PrI) climate.

\subsection{Astronomical and GHG forcings}

MIS-13.1 spans a full precession cycle: perihelion occurred in NH summer at $485 \mathrm{ka} \mathrm{BP}\left(\varpi=268.25^{\circ}, e=0.03857\right.$, $\left.\varepsilon=23.212^{\circ}\right)$, then in winter at $495 \mathrm{kaBP}\left(\varpi=97.82^{\circ}\right)$ and in summer again at $506 \mathrm{kaBP}\left(\varpi=274.05^{\circ}\right)$. The model was thus run for the orbital configurations of $495 \mathrm{ka}$ and 

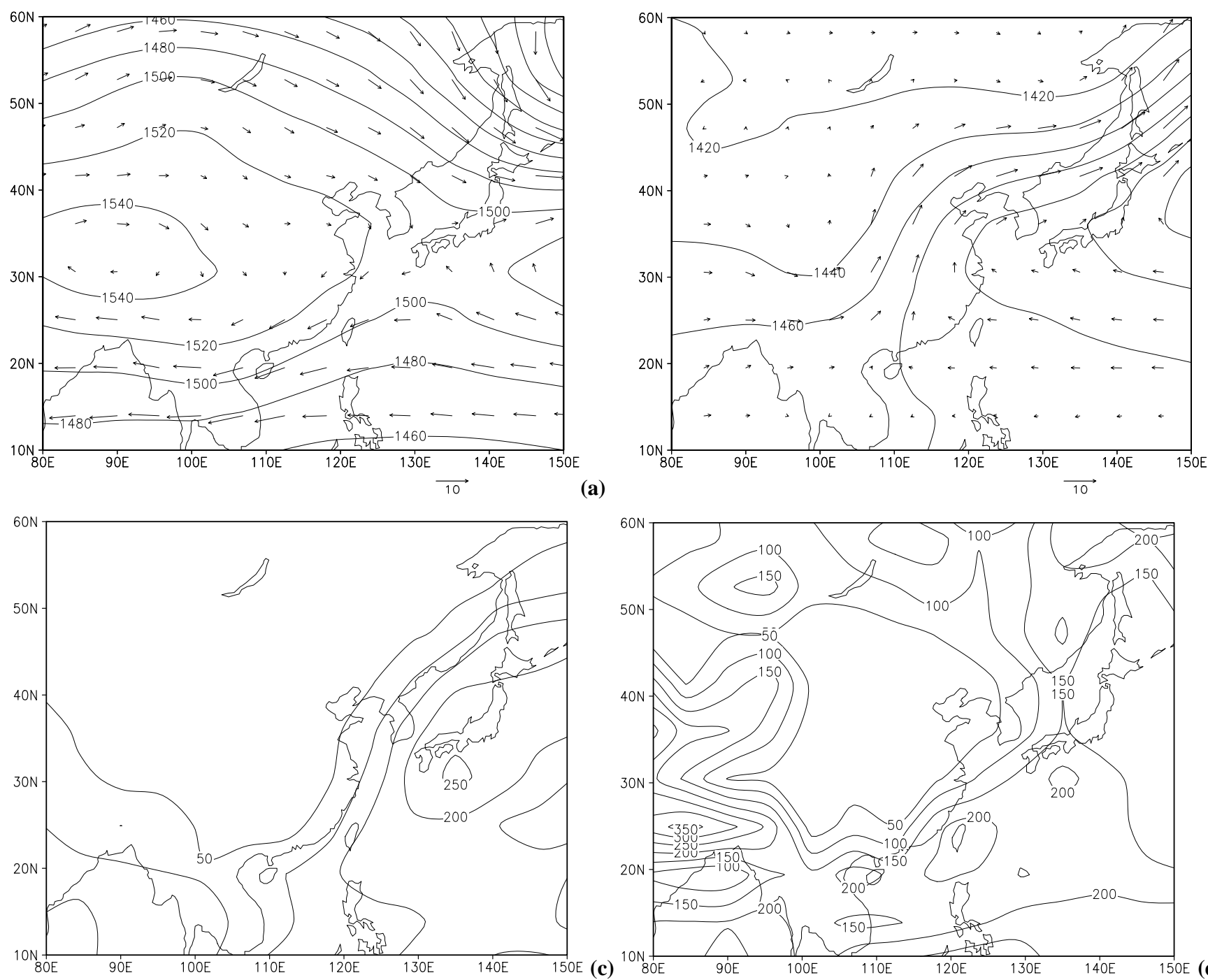

(a)

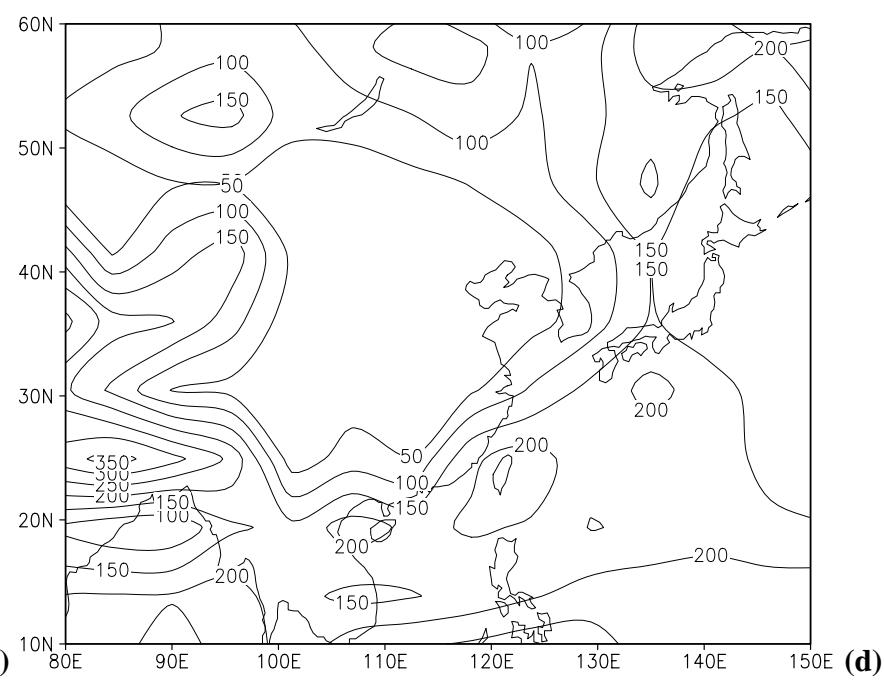

Fig. 1. Present-day climate simulated by LOVECLIM. (a) January $850 \mathrm{hPa}$ geopotential height (m) and wind (m/s), (b) July $850 \mathrm{hPa}$ geopotential height $(\mathrm{m})$ and wind $(\mathrm{m} / \mathrm{s})$, (c) January precipitation $(\mathrm{cm} /$ year) and (d) July precipitation $(\mathrm{cm} / \mathrm{year})$.

$506 \mathrm{ka} \mathrm{BP}$, but not for $485 \mathrm{ka} \mathrm{BP}$ given that it is very similar to $506 \mathrm{ka} \mathrm{BP}$. Note that the isotopic signals of MIS-13.11 and MIS-13.13 peaked a few thousand years later than $485 \mathrm{ka} \mathrm{BP}$ and $506 \mathrm{ka} \mathrm{BP}$, respectively, which is not surprising given the response time of ice sheets. However, we used the extremes of the precession cycle because we are interested in monsoon and the latter is expected to be primarily controlled by precession.

As the strong EASM extends over MIS-13.3 also, it was decided to include this other peak of interglacial MIS-13 in our simulations. Although the ice volume minimum is in fact situated around $524 \mathrm{ka} \mathrm{BP}$, we have adopted the conservative strategy of coupling the minimum ice volume with maximum summer insolation and therefore have chosen a date of $529 \mathrm{ka} \mathrm{BP}$ for the MIS-13.3 experiment as it corresponds to the summer solstice at perihelion (Exp. 8 and Exp. 9 in Table 1).

Being given the revised time scale of EPICA in Jouzel et al. (2007) and the $\mathrm{CO}_{2}, \mathrm{CH}_{4}$ and $\mathrm{N}_{2} \mathrm{O}$ concentration given in Siegenthal et et al. (2005) and Spahni et al. (2005), it was decided to use the same GHG concentration both for 506 and 495 ka BP MIS-13.1 experiments (Exp. 2 to Exp. 7 in Table 1). This hypothesis seems acceptable because the GHG values for these two dates are not much different, and averages over that period were used. Taking the same values for the whole MIS-13.1 makes it easier also to test the sensitivity of the climate model to the astronomical forcing alone, in particular to precession. 
Table 1. The forcings for the different simulations. In this table, $0 \mathrm{ka} \mathrm{BP}$ is for Pre-Industrial time, and its greenhouse gases concentration values are used in the Paleoclimate Modeling Intercomparison Project (Braconnot et al., 2007). Ice sheets means North American and Eurasian ice sheets.

\begin{tabular}{|c|c|c|c|c|c|c|c|c|c|}
\hline $\begin{array}{c}\text { Experiments } \\
\text { No. }\end{array}$ & $\begin{array}{c}\text { Time } \\
(\mathrm{ka} \mathrm{BP})\end{array}$ & $\begin{array}{c}\mathrm{CO}_{2} \\
\text { (ppmv) }\end{array}$ & $\begin{array}{c}\mathrm{CH}_{4} \\
(\mathrm{ppbv})\end{array}$ & $\begin{array}{l}\mathrm{N}_{2} \mathrm{O} \\
(\mathrm{ppbv})\end{array}$ & Eccentricity & $\begin{array}{l}\text { Obliquity } \\
\left(^{\circ}\right)\end{array}$ & $\begin{array}{l}\text { Longitude of Perihelion } \\
\qquad\left({ }^{\circ}\right)\end{array}$ & $\begin{array}{c}\text { Ice } \\
\text { sheets }\end{array}$ & $\begin{array}{l}\text { Tibetan } \\
\text { Plateau }\end{array}$ \\
\hline Exp. 1 & 0 & 280 & 760 & 270 & 0.016724 & 23.446 & 102.04 & No & Yes \\
\hline Exp. 2 & 495 & 240 & 510 & 280 & 0.038638 & 23.903 & 97.82 & No & Yes \\
\hline Exp. 3 & 495 & 240 & 510 & 280 & 0.038638 & 23.903 & 97.82 & Yes & Yes \\
\hline Exp. 4 & 506 & 240 & 510 & 280 & 0.034046 & 23.377 & 274.05 & No & Yes \\
\hline Exp. 5 & 506 & 240 & 510 & 280 & 0.034046 & 23.377 & 274.05 & Yes & Yes \\
\hline Exp. 6 & 506 & 240 & 510 & 280 & 0.034046 & 23.377 & 274.05 & No & No \\
\hline Exp. 7 & 506 & 240 & 510 & 280 & 0.034046 & 23.377 & 274.05 & Yes & No \\
\hline Exp. 8 & 529 & 240 & 530 & 280 & 0.015078 & 23.622 & 268.25 & No & Yes \\
\hline Exp. 9 & 529 & 240 & 530 & 280 & 0.015078 & 23.622 & 268.25 & Yes & Yes \\
\hline
\end{tabular}

\subsection{North American (NA) and Eurasian (EA) ice sheets}

The Greenland and Antarctica ice sheets were kept the same as for the present-day in all the simulations (the present-day ice volume is about $2.9 \times 10^{6} \mathrm{~km}^{3}$ for Greenland ice sheet and $24.7 \times 10^{6} \mathrm{~km}^{3}$ for Antarctica ice sheet (IPCC, 2007)). $\delta^{18} \mathrm{O}$ of deep-sea cores clearly suggest the existence of other ice sheets in the Northern Hemisphere during MIS-13, but it is unfortunately difficult to assess their exact area and volumes. The latter were therefore estimated by extrapolating the information available from their LGM reconstruction using $\delta^{18} \mathrm{O}$ - ice volume - sea level generic relationships. We hypothesize that the LGM total ice volume for both NA and EA was $39 \times 10^{6} \mathrm{~km}^{3}$, a mid-range value estimated from Hughes et al. (1981), Peltier (1994, 1998, 2004), Clark and Mix (2002), Lambeck et al. (2002), and Bintanja et al. (2005). This value is actually pretty close to the ICE-4G (Peltier, 1994) LGM reconstruction $\left(36.1 \times 10^{6} \mathrm{~km}^{3}\right)$. The ratio between the excess of ice at the LGM compared to today and that at MIS-13.1 is estimated from the $\delta^{18} \mathrm{O}$ taken from Imbrie et al. (1984). This leads an ice volume of $11 \times 10^{6} \mathrm{~km}^{3}$ of ice at MIS-13.1 and $16.6 \times 10^{6} \mathrm{~km}^{3}$ of ice at MIS-13.3 to be distributed between NA and EA. We can either assume the ratio between NA and EA was the same as at the LGM (NA is about twice EA in the LGM scenario) or follow Bintanja et al.'s (2005) reconstruction (EA is about twice NA in the Bintanja scenario).

For MIS 13.1, this strategy leads to an ice volume of 7.3 and $3.7 \times 10^{6} \mathrm{~km}^{3}$ for respectively NA and EA in the LGM scenario or to 3.7 and $7.3 \times 10^{6} \mathrm{~km}^{3}$ in the Bintanja scenario. Other reconstructions were calculated based on the $\delta^{18} \mathrm{O}$ values of Bassinot et al. (1994), Lisiecki and Raymo (2005), Shackleton (2000) and Tiedemann et al. (1994). Using the LGM reconstruction of the NA and EA ice sheet volumes from Peltier (1994) as a reference for the proportionality rule leads to MIS-13.1 ice volumes ranging from 1.06 to $4.14 \times 10^{6} \mathrm{~km}^{3}$ for EA and from 2.15 to $8.42 \times 10^{6} \mathrm{~km}^{3}$ for NA. Corresponding sensitivity studies will be published elsewhere but we anticipate in saying that the conclusions reached in the present paper are qualitatively insensitive to the details of the adopted reconstruction.

Ice sheets are assumed to be axi-symmetric. For a given maximum thickness, $h$, and a diameter of the circular basis at the ground, $l$, the volume of such ice sheet is

$V=2 \pi h l^{2} / 15$

The thickness of the ice sheet at each grid point can be calculated assuming that we know the relationship between $h$ and $l$ and the location of the ice sheet centre.

As a first approximation, the relationship between $h$ and $l$ can be estimated from the shape and size of the ice sheets at the LGM. At MIS-13.1, the diameter of NA is about $2600 \mathrm{~km}$ and the altitude of its crest above the ground about $1700 \mathrm{~m}$. For EA, these values are roughly $2000 \mathrm{~km}$ and $1480 \mathrm{~m}$. At MIS-13.3, these are for NA, $2980 \mathrm{~km}$ and $1985 \mathrm{~m}$ respectively and for EA $2280 \mathrm{~km}$ and $1690 \mathrm{~m}$. These values were used in the present paper but we note that according to a theoretical model by Paterson (1994) $l$ is proportional to $h^{2}$, which leads to slightly different ice sheets properties. Again, these details do not qualitatively affect our conclusions.

Finally, the locations of NA and EA were based on what we know from the initiation of the ice sheets at the last glacial inception (Clark et al., 1993; Bintanja et al., 2002; Peltier, 2004). For NA, we assumed that its center was at $\left(90^{\circ} \mathrm{W}\right.$, $\left.69^{\circ} \mathrm{N}\right)$ and for $\mathrm{EA},\left(50^{\circ} \mathrm{E}, 63^{\circ} \mathrm{N}\right)$. Simulations were also made assuming EA is located over Scandinavia (centered at $28^{\circ} \mathrm{E}, 63^{\circ} \mathrm{N}$ ). Although these are interesting features to be discussed in relationship with this change in location, the main conclusions remain again unchanged.

In summary, we will discuss eight experiments (Table 1). Three of them (Exp. 2, 4 and 8) allow to isolate the effect of changing only the astronomical parameters: they are made respectively for 495,506 and $529 \mathrm{ka} \mathrm{BP}$. Three others (Exp. 3, 5 and 9) test the effect of the ice sheets themselves. 
Table 2. Globally averaged surface temperature and precipitation over East China for the 495, 506 and $529 \mathrm{ka}$ BP experiments. All the values are relative to the simulated Pre-Industrial ones.

\begin{tabular}{lrrrrrr}
\hline Experiments & \multicolumn{3}{c}{ Global Surface temperature $\left({ }^{\circ} \mathrm{C}\right)$} & \multicolumn{2}{c}{ Precipitation over East China (\%) } \\
\hline & January & July & Annual & January & July & Annual \\
Exp. 2 & -0.08 & -0.99 & -0.41 & 0 & -16 & -5 \\
Exp. 4 & -1.07 & 0.84 & -0.18 & -5 & 32 & 7 \\
Exp. 5 & -1.7 & 0.58 & -0.64 & -15 & 37 & 2 \\
Exp. 8 & -0.75 & 0.46 & -0.18 & -5 & 18 & 4 \\
Exp. 9 & -1.47 & 0.04 & -0.75 & -10 & 21 & -4 \\
\hline
\end{tabular}

They are made for the the same time slices which will therefore allow them to be compared with Exp. 2, 4 and 8. The last two experiments (Exp. 6 and 7) concern the sensitivity to the Tibetan Plateau at $506 \mathrm{ka}$ BP. Comparing experiments 7 (with ice sheets) and 6 (without ice sheets) shows the impact of the ice sheets in absence of the Tibetan Plateau. This will in turn be compared to the difference between experiments 5 and 4, a difference which shows the effect of the ice sheets in presence of the Tibetan Plateau. All the experiments are 2000-year long simulations and the climate averages are computed over the last 100 years.

\section{Climate response at 495 and $506 \mathrm{ka} \mathrm{BP}$ (MIS-13.1)}

Table 2 summarizes the global surface temperature and July precipitation over East China simulated for MIS-13.1 and 13.3 (East China is defined as a region from 100 to $120^{\circ} \mathrm{E}$ and 20 to $40^{\circ} \mathrm{N}$, including 25 grids points of LOVECLIM with an area of $4.3 \times 10^{6} \mathrm{~km}^{2}$ ). $506 \mathrm{ka}$ BP (Northern Hemisphere summer at perihelion, Exp. 4) is globally warmer than 495 (Southern Hemisphere summer at perihelion, Exp. 2), both in July and in annual mean. This result is consistent with other experiments we have made (not shown here) where we tested the effect of changing the precession phase by $180^{\circ}$. It underlines the importance of the Northern Hemisphere response and associated feedbacks at the global scale. Besides this increase in temperature, astronomical situations with summer at perihelion are also associated with a stronger EASM. In July, the precipitation over East China increases by $32 \%$ at $506 \mathrm{ka} \mathrm{BP}$ (Exp. 4, Table 2) as compared to PreIndustrial one, but it decreases by $16 \%$ at $495 \mathrm{ka} \mathrm{BP}$ (Exp. 2). This means that there is far more precipitation in July over East China at $506 \mathrm{ka} \mathrm{BP}$ than at $495 \mathrm{ka} \mathrm{BP}$ owing to the enhanced seasonal contrast (Table 2). Actually, this is also true for the regions affected by the African and the Indian monsoon. For example, precipitation increases by $60 \%$ at $506 \mathrm{ka} \mathrm{BP}$ as compared to Pre-Industrial one over North Africa $\left(0-30^{\circ} \mathrm{N}, 20^{\circ} \mathrm{W}-60^{\circ} \mathrm{E}\right)$, whereas it decreases by $20 \%$ at $495 \mathrm{kyr} \mathrm{BP}$. Over India $\left(10-27^{\circ} \mathrm{N}, 70-90^{\circ} \mathrm{E}\right)$, these numbers are respectively $+29 \%$ and $-10 \%$. So far these results essentially provide a further confirmation of the common un- derstanding of the effect of precession on temperature and monsoon precipitation.

By contrast, the further reinforcement of EASM precipitation in response to the introduction of ice sheets (Exp. 5) is surprising because one could think that the continental cooling associated with the ice sheets is unfavorable to monsoon dynamics. The July precipitation anomaly resulting from the introduction of ice sheets at $506 \mathrm{kaBP}$ is shown on Figs. 2 (global) and 3a (East Asia). These are differences between Exp. 5 (with ice sheets) and Exp. 4 (without ice sheets). Also shown is the statistical significance (at both the $95 \%$ and $99.9 \%$ confidence levels) of the anomalies using a Student t-test. The introduction of ice sheets causes a decrease in precipitation over a band extending from North Africa to Saudi Arabia continuing to the Western Siberian Lowlands, and also over northeastern China and most of Japan (Fig. 2). By contrast, precipitation increases over most of the western part of the Indian subcontinent and over the east of the Arabian Sea. More important for our purpose, two main bands with increased rainfall are clearly seen over East Asia. One is south of $35^{\circ} \mathrm{N}$, extending from the eastern margin of the Tibetan Plateau through South China and South Japan and disappearing over the Pacific Ocean. In this belt, precipitation increases from a few percent to $30 \%$ (in qualitative agreement with proxy data, e.g. Guo et al., 1998; Yin and Guo, 2006, 2008). This region extends over about $1200 \mathrm{~km}$ in latitude and $4200 \mathrm{~km}$ in longitude and it includes 24 grid points in LOVECLIM (the resolution of which is about $5.6^{\circ} \times 5.6^{\circ}$ ). The other band extends from the northern margin of the Tibetan Plateau, through the northwest of China and Mongolia, and finally to the north of Lake Baikal. This effect of the ice sheets on the East Asian precipitation is much larger than the interdecadal variability. All precipitation changes greater than roughly $10 \mathrm{~cm} /$ year are significant at the $95 \%$ confidence level at least. In particular, the center part of the anomalies associated with the wave train discussed here below is significant at $99 \%$ confidence level. Similar confidence levels are reached in all other experiments, like those where the size of the ice sheets is reduced or increased by a factor of two, and those where the center of the Eurasian ice sheet is moved westward $1000 \mathrm{~km}$ to be placed finally over 


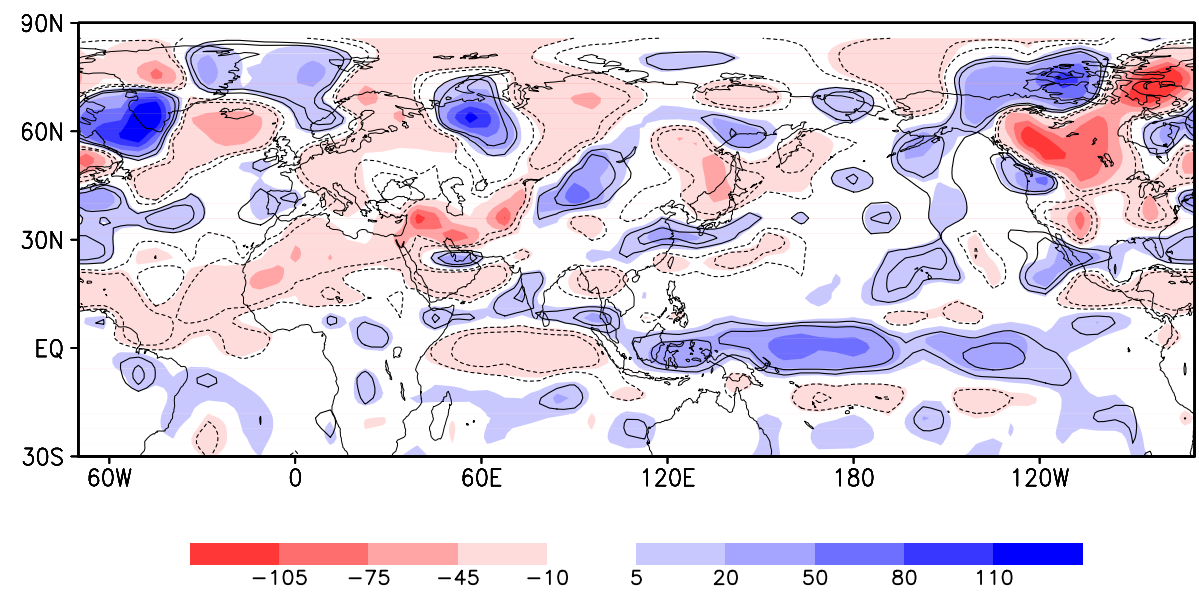

Fig. 2. July precipitation difference between Exp. 5 (with ice sheets) and Exp. 4 (without ice sheets). The color shading indicates precipitation anomaly in cm/year and the contour lines limit the regions where the anomalies are significant at the $95 \%$ and $99.9 \%$ confidence levels.

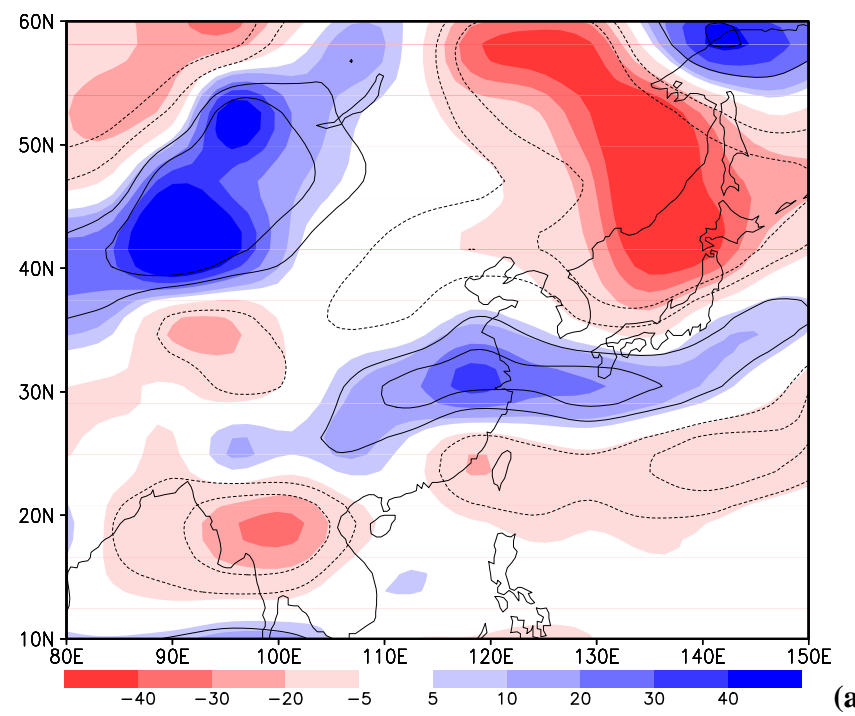

(a)

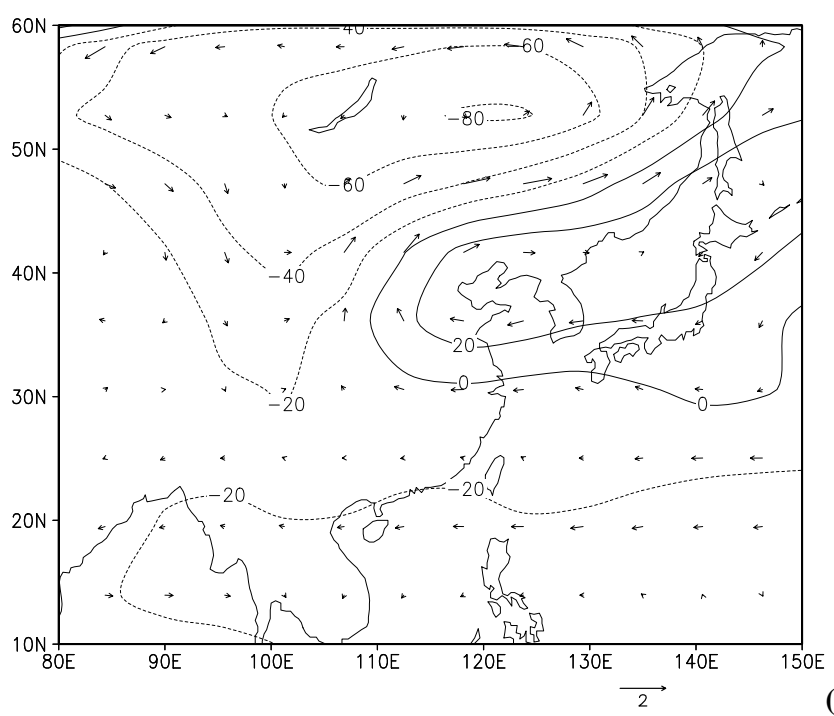

(b)

Fig. 3. Exp. 5 minus Exp. 4 for (a) July precipitation (cm/year) and (b) July geopotential $\left(\mathrm{m}^{2} \mathrm{~s}^{-2}\right)$ and wind (m/s) at $800 \mathrm{hPa}$ level. In (a) color shading and contour lines of confidence levels are like in Fig. 2.

Scandinavia (see here below remarks about the impact of the size and geographical location of the Eurasian ice sheet). This precipitation anomaly pattern is also robust on using another 100-yr time sampling of the model output time series.

It is also significant that the pressure gradient between the ocean and the continent gets larger when the ice sheets are introduced (Fig. 3b). High geopotential over the ocean becomes larger and low geopotential deepens over land. The gradient between the ocean and the continent increases by $10-15 \%$ from the "no ice sheet" (Exp. 4) to the "with ice sheets" (Exp. 5) experiment. Consistently, we observe a reinforcement of the easterlies blowing from the ocean to the continent, an enhanced convergence and more convective precipitation over East China. Along the coast of South-
East China, the wind velocity increases by 10 to $20 \%$ and becomes definitely more easterly. At the same time, the westerly component of the wind over the continent (blowing towards the ocean) intensifies, and convergence over central China increases, which is normally expected to favor precipitation. In particular, the water vapor flux from the ocean to the continent is seen to increase (by $26 \%$ at $124^{\circ} \mathrm{E}-30^{\circ} \mathrm{N}$ for example) mainly in response to the increase in the easterly wind (from 1.6 to $2.1 \mathrm{~ms}^{-1}$ ). An analysis of the water budget in the main center of precipitation increase $\left(\sim 118^{\circ} \mathrm{E}-30^{\circ} \mathrm{N}\right)$ further reveals that the precipitation change is due for $58 \%$ to the evaporation change and $42 \%$ to change in the divergence of the water vapor flux. 

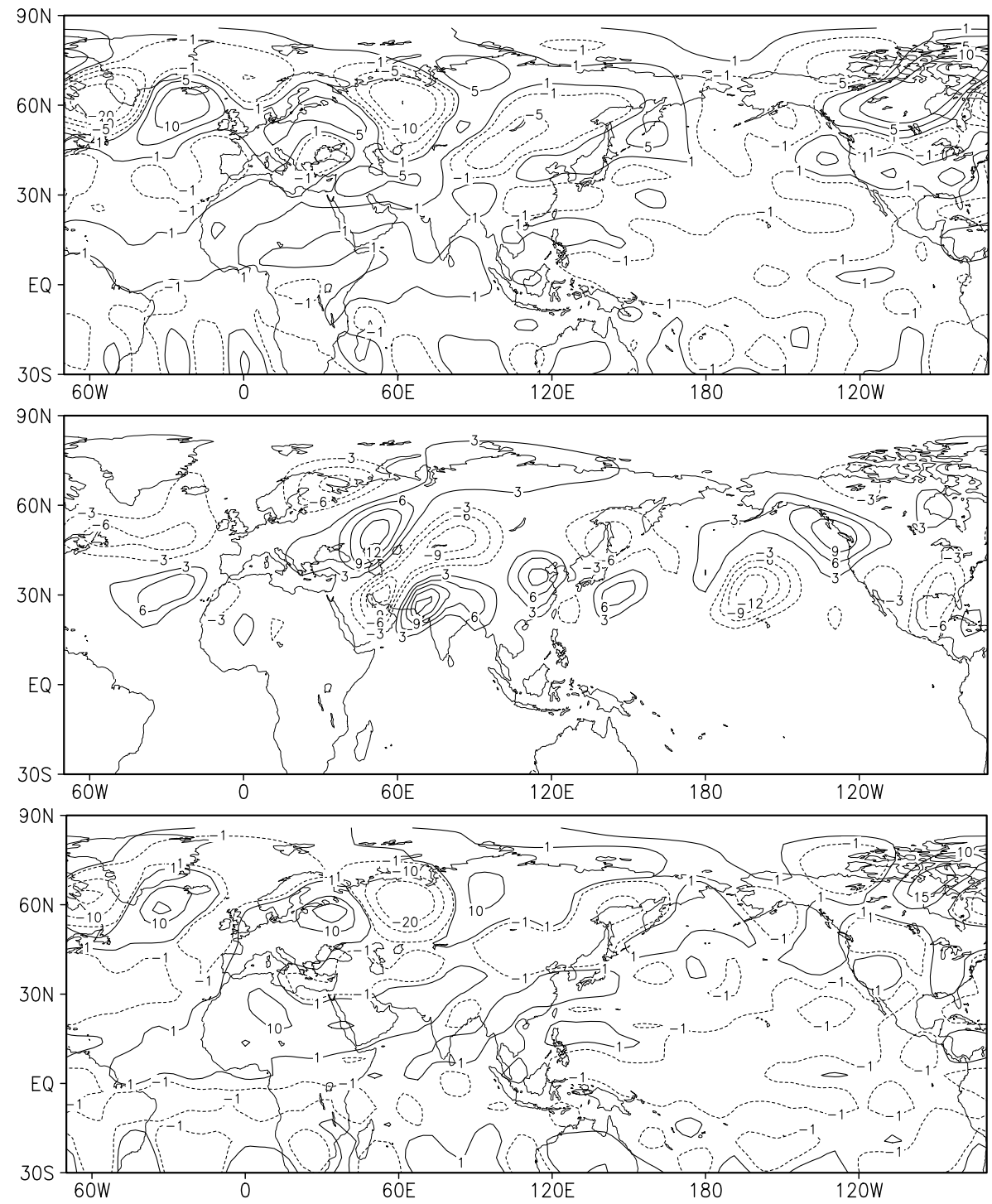

Fig. 4. (a) Upper, difference for July 650-hPa-level omega field (in $0.001 \mathrm{~Pa} / \mathrm{s}$ ) between Exp. 5 (with ice sheets) and Exp. 4 (without ice sheets); (b) Middle, same as (a) but for January; (c) Lower, difference for July 650-hPa-level omega field (Pa/1000s) between Exp. 7 (with ice sheets) and Exp. 6 (without ice sheets) in the absence of Tibetan Plateau.

While a reinforcement of the summer monsoon with the Northern Hemisphere summer occurring at perihelion was expected, the reinforcement caused by the ice sheets is harder to figure out. The difference in July precipitation between the experiment with ice sheets (Exp. 5) and the one without ice sheet (Exp. 4) (Fig. 2) shows that zone of dry anomaly develops to the West of the Eurasian ice sheet. It results from anticyclonic vorticity forced over the upslope region. Conversely, a wet anomaly develops to the East, due to cyclonic vorticity forced over the downslope region. Both are expected consequences of the principle of conservation of potential vorticity (see, e.g. Holton 1979:87-91). Even more significant is the appearance of a wave train structure prop- agating south-eastwards starting from the EA ice sheet and ending up over East China with a reinforcement of precipitation. This wave train exactly corresponds to the barotropic model results of Grose and Hoskins (1979) where such a wave train is topographically induced. This wave feature is also seen in LOVECLIM in the 650-hPa-level omega field (Fig. 4a), with alternating large scale ascent and subsidence ending up with a reinforcement of the ascent over China.

This wave train is actually a robust feature of LOVECLIM. It appears also with more or less the same intensity, the same direction and the same wavelength in the following experiments: 


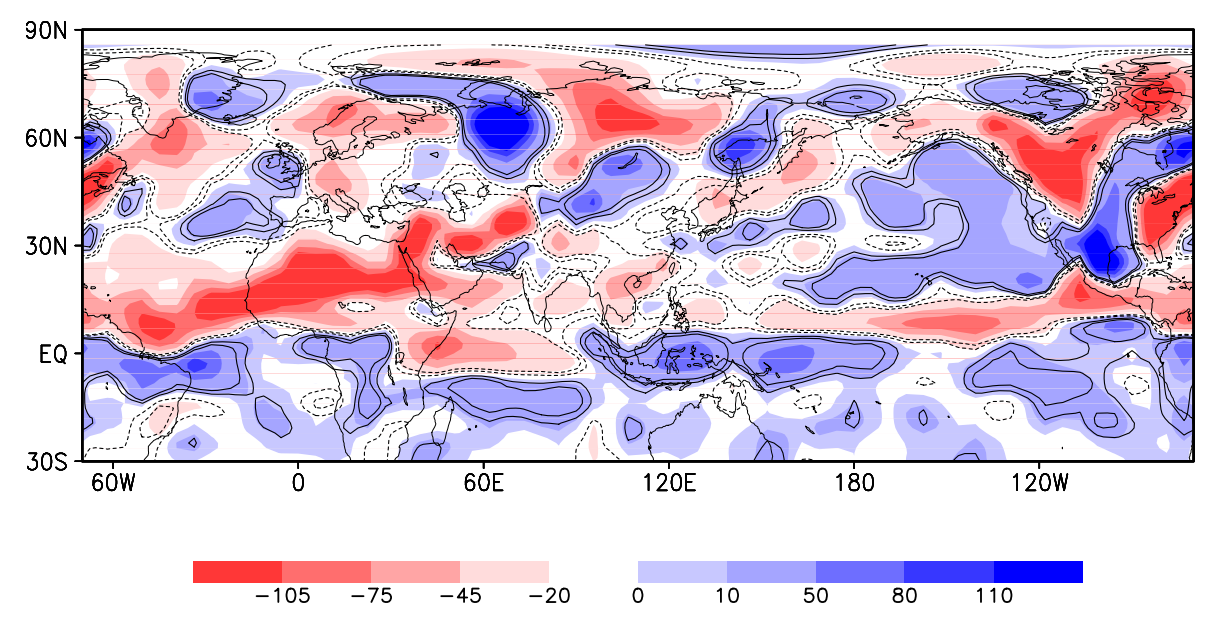

Fig. 5. July precipitation difference between with and without ice sheets experiments where the 506 ka BP ice sheets volumes are assumed to be the same as they were at the Last Glacial Maximum and the centre of the NA ice sheet is moved one grid point to the south of its LGM position. Color shading and contour lines of confidence levels are like in Fig. 2.

1. other 100-yr long experiments with the same forcing and boundary conditions as used here.

2. an experiment where the size of the EA ice sheet is doubled according to the reconstruction by Bintanja et al. (2005).

3. an experiment using a shape according to the Paterson's model assuming a perfectly plastic ice.

4. an experiment where the EA ice sheet has been moved westward $1000 \mathrm{~km}$ to finally be placed over Scandinavia. In this case the direction of the wave train changes only very slightly. The wave train continues to end up over East China with more precipitation which therefore does not change our conclusion.

5. an experiment with the same GHG concentration and ice sheets, but with $\mathrm{NH}$ winter at perihelion.

As far as the ice sheet size is concerned, sensitivity experiments (not illustrated here) show that there is a threshold value beyond which the EASM weakens, but only if the center of the NA ice sheet is moved south of its LGM position. When the sizes of the $506 \mathrm{ka}$ BP ice sheets are over that threshold, the wave-length of the wave train is such that it does not phase lock any more with the EASM. The center of maximum precipitation increase (as compared to the no ice sheets experiment) falls in the Pacific Ocean (Fig. 5). In all cases before reaching this threshold, the results remain more or less the same as discussed here for Fig. 2.

We have so far no clear explanation on why the wave train adjusts such as to reinforce the EASM, in other words, what is the phase-locking mechanism. It may be related to the Pacific Ocean, the Tibetan Plateau and/or the thermal low over East Asia. In favor of the last possibility though, we find that in January (Fig. 4b), there is a wave train in the omega field like in July, but it is ending this time with a large scale subsidence which reinforces the winter thermal High over China. We also performed experiments where Tibetan Plateau was removed. Comparing again the experiments with (Exp. 7) and without (Exp. 6) ice sheets in the absence of the Tibetan Plateau, the wave train is still very much present, especially in the omega field at $650 \mathrm{hPa}$ level (Fig. 4c), but with a different wave-length. The ascent previously centered over East China (Fig. 4a) is now over the west Pacific and is replaced by a subsidence (Fig. 4c). This leads to July precipitation over East China being 7\% less in Exp. 7 than in Exp. 6. In this case, we would tentatively conclude that the EA ice sheet reinforces the summer precipitation over East China only through the influence of the Tibetan Plateau, the latter being instrumental in shaping the configuration of the wave train.

The existence of the wave train is justified by the barotropic and baroclinic theories summarized by Grose and Hoskins (1979) and Hoskins and Karoly (1981). However, we appreciate that the particular configuration that it adopts in the LOVECLIM model could be model dependent. This will be tested by further investigating with other climate models the mechanisms by which this wave is generated and phase-locked.

Numerical experiments made for MIS-13.1 show therefore that the precipitation over China associated to the EASM is much stronger when Northern Hemisphere summer is at perihelion rather than when Southern Hemisphere summer is at perihelion, and that it gets reinforced again after the ice sheets are introduced. These two reinforcements lead actually to create a monsoon which is stronger at $506 \mathrm{ka} \mathrm{BP}$ than at the Pre-Industrial. July precipitation over East China in the experiment $506 \mathrm{ka} \mathrm{BP}$ with ice sheets (Exp. 5) increases 

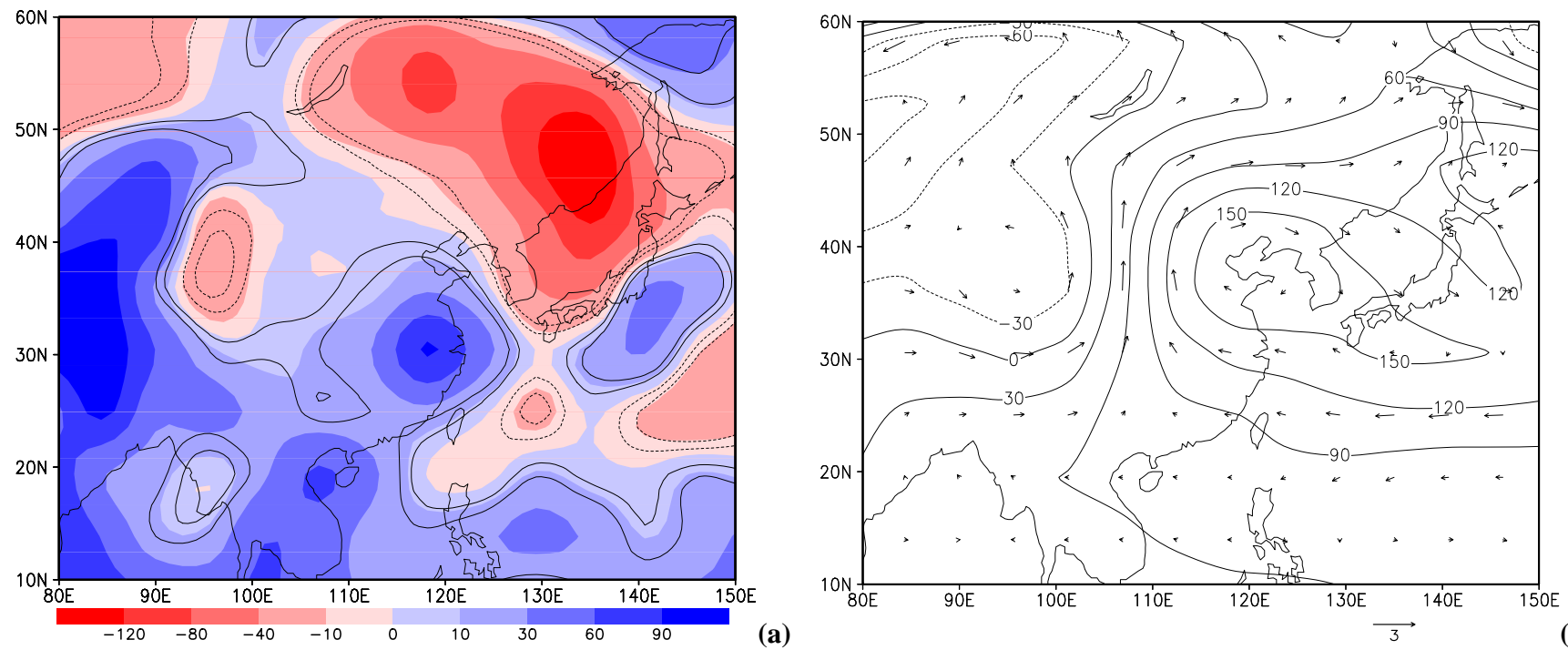

Fig. 6. Exp. 5 (506 ka BP with ice sheets) minus Exp. 1 (Pre-Industrial) for (a) July precipitation (cm/year) and (b) July geopotential ( $\mathrm{m}^{2} \mathrm{~s}^{-2}$ ) and wind (m/s) at $800 \mathrm{hPa}$ level. In (a) color shading and contour lines of confidence levels are like in Fig. 2.

by about $37 \%$ when compared to the Pre-Industrial one (Table 2, Fig. 6a). This increase of precipitation over East China is in qualitative agreement with the reconstruction made from the proxy records in China. At the same time, July geopotential increases over the ocean and decreases over the continent (Fig. 6b). This means that the pressure gradient between the ocean and the continent increases, leading to a 20 to $80 \%$ increase in the southwesterly and southeasterly wind velocity at the $800 \mathrm{hPa}$ level over China. This leads to an increase of the water vapor flux from the ocean to the continent and to a general strengthening of the East Asian summer monsoon. Besides the evaporation process, the overall influence of the ocean would deserve to be discussed (Ohgaito and Abe-Ouchi, 2007). It would be worth testing the relative contribution of the atmospheric convergence and of the sea surface temperature to the increase of water vapor flux.

\section{Climate response at $529 \mathrm{ka} \mathrm{BP}$ (MIS-13.3)}

We decided to analyze the climate during MIS-13.3 because the proxy records from China show that the strong EASM occurred during the period from about 530 to $480 \mathrm{ka} \mathrm{BP}$ (e.g. Kukla et al., 1990; Guo et al., 1998), and also because the extreme monsoon over South Asia and Africa occurred near 525-530 ka BP, which is closer to MIS-13.3 than to MIS-13.1 (Bassinot et al., 1994; Rossignol-Strick et al., 1998).

As discussed earlier in Sect. 3, the peak of MIS-13.3 dates $524 \mathrm{ka} \mathrm{BP}$ and the selected astronomical forcing for it is at $529 \mathrm{ka} \mathrm{BP}$. The astronomical situations at 529 and $506 \mathrm{ka} \mathrm{BP}$ differ essentially through eccentricity which is much smaller at $529 \mathrm{ka} \mathrm{BP}$ (0.015 against 0.034 at $506 \mathrm{ka} \mathrm{BP})$. This means that at $529 \mathrm{ka} \mathrm{BP}$, the distance of the Earth to the Sun at perihelion is larger leading to less energy available in Northern Hemisphere summer ("cooler" summer), but also to less energy globally averaged over the Earth and the year, $W$, because $W=S_{0} /\left(1-e^{2}\right)^{1 / 2}$ implies that $W$ is smaller for smaller values of $e$. This "cooler" Northern Hemisphere summer at $529 \mathrm{ka} \mathrm{BP}$ is companied by the Eurasian continent being cooler by 1 to $3^{\circ} \mathrm{C}$ relative to $506 \mathrm{ka} \mathrm{BP}$ (not shown here), and by a slightly cooler $\left(0.3^{\circ} \mathrm{C}\right)$ over northern Pacific and slightly warmer $\left(0.6^{\circ} \mathrm{C}\right)$ over Okhotsk and Bering seas. This reduces the thermal gradient between the land and the adjacent ocean leading to a weaker summer monsoon at $529 \mathrm{ka} \mathrm{BP}$ than at $506 \mathrm{ka}$ BP. Consequently, July precipitation over East China is $11 \%$ less at $529 \mathrm{ka} \mathrm{BP}$ than at $506 \mathrm{ka} \mathrm{BP}$. There is also less July precipitation over North Africa and India.

At $529 \mathrm{ka} \mathrm{BP}$, when the ice sheets are introduced, the same wave train as at $506 \mathrm{ka} \mathrm{BP}$ is observed in the precipitation and omega fields. Actually, all the $529 \mathrm{ka} \mathrm{BP}$ regional features are about the same as at $506 \mathrm{ka} \mathrm{BP}$. Although weaker than at $506 \mathrm{ka}$ BP, July precipitation over East China at MIS-13.3 is still 21\% more abundant than the Pre-Industrial one (Fig. 7a) and the wind velocity is 10 to $40 \%$ larger (Fig. 7b). It is therefore not surprising that the proxy data record a strong EASM during the whole MIS-13. The environment has indeed been affected already strongly by the early monsoon during MIS-13.3. This first impact has been definitely imprinted in the proxy records and reinforced later during MIS13.13 and MIS-13.11. 

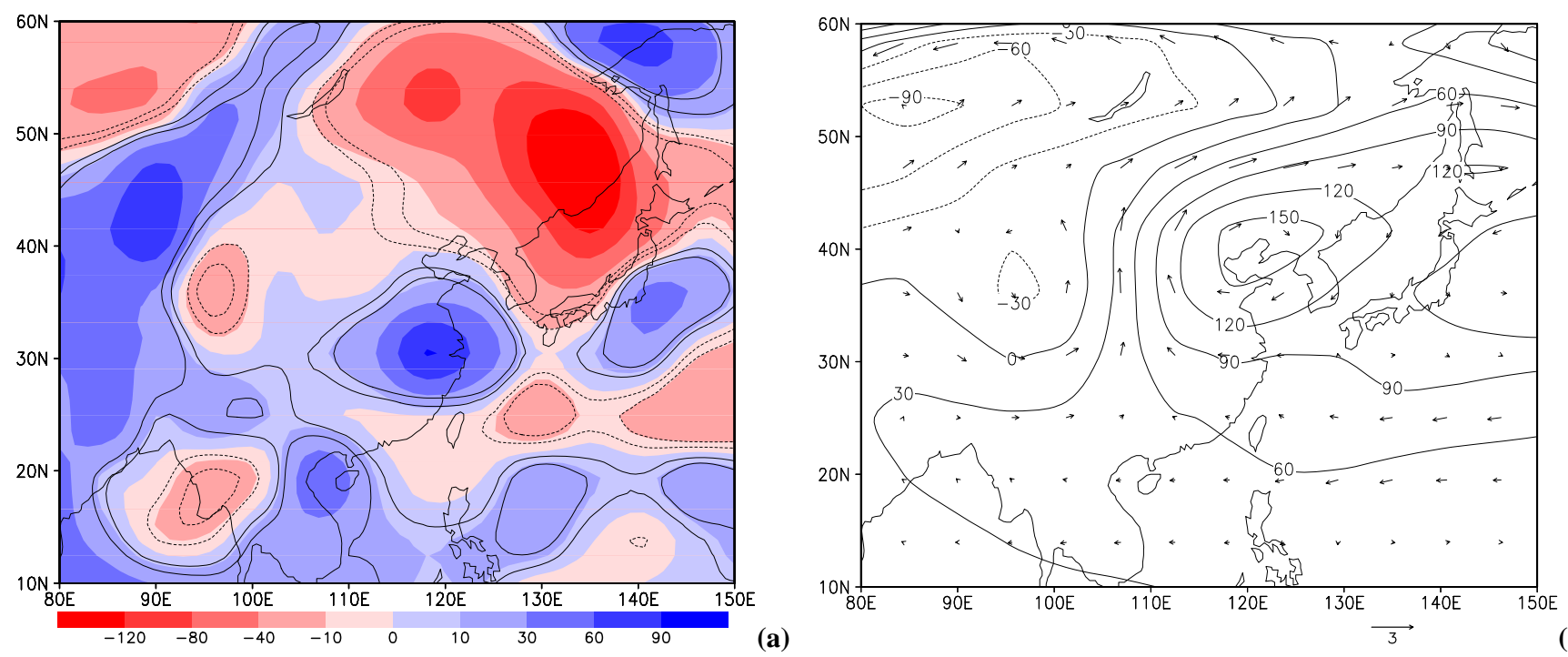

Fig. 7. Exp. 9 (529 ka BP with ice sheets) minus Exp. 1 (Pre-Industrial) for (a) July precipitation (cm/year) and (b) July geopotential ( $\mathrm{m}^{2} \mathrm{~s}^{-2}$ ) and wind $(\mathrm{m} / \mathrm{s})$ at $800 \mathrm{hPa}$ level. In (a) color shading and contour lines of confidence levels are like in Fig. 2.

\section{Conclusions}

For the first time, a series of modelling experiments have been made to understand the palaeo-environmental data showing an exceptionally strong East Asian summer monsoon occurring during the cool MIS-13 interglacial. The main conclusions, using the LOVECLIM model, underline the major role played by both the astronomical and ice sheet forcings, the last mainly through teleconnection:

1. When the Northern Hemisphere summer occurs at perihelion, like at both 529 and $506 \mathrm{ka} \mathrm{BP}$, the large seasonal contrast leading to the East Asian summer monsoon is more intense than when Southern Hemisphere summer occurs at perihelion, like at $495 \mathrm{ka} \mathrm{BP}$ and Pre-Industrial time.

2. The Eurasian ice sheet (its albedo and topography which was deduced from the $\delta^{18} \mathrm{O}$ record) further enhances the summer precipitation over East China through a wave train propagating south-eastwards from the Eurasian ice sheet. This wave train ending with a large scale ascent over East China is influenced by the Tibetan Plateau and probably phase locked by the East Asian summer low. A consistent pattern of responses is then observed, made of an increase of the air pressure gradient between the Pacific Ocean and the East Asian continent, an intensification of the low-level south-easterlies blowing from the ocean and an enhanced precipitation over East China. These preliminary results make sense because they are overall consistent with beta-plane atmosphere dynamics theory. However, they still need to be substantiated by other more sophisticated climate models, by further sensitivity analyses to the volume and location of the ice sheets and to the size of the Tibetan Plateau and by investigation of the wave phase-lock process.

3. The regional features at $529 \mathrm{ka} \mathrm{BP}$ are very similar to those at $506 \mathrm{ka} \mathrm{BP}$. It is not surprising that the proxy data record a strong EASM during the whole MIS-13.

In summary, although the model simulates a situation at 506 and $529 \mathrm{kaBP}$ which is globally cooler than at PreIndustrial time due to the ice sheets and a lower greenhouse gases concentration, both the Northern Hemisphere summer at perihelion and the atmospheric wave induced by the Eurasia ice sheet lead to a stronger monsoon than at Pre-Industrial time. This strong monsoon finally contributes to increase the tree fraction over most of China (not shown here), which within the resolution of the model fits well the paleo-record.

Acknowledgements. Qiuzhen Yin has benefited from a grant of the Belgium FNRS (Fonds de la Recherche Scientifique) and is now postdoctoral fellow at Université catholique de Louvain in Louvain-la-Neuve. M. Crucifix and H. Goosse are research associates with the FNRS.

Edited by: P. Braconnot 


\section{References}

Bassinot, F. C., Labeyrie, L. D., Vincent, E., Quidelleur, X., Shackleton, N. J., and Lancelot, Y.: The astronomical theory of climate and the age of the Brunhes-Matuyama magnetic reversal, Earth Planet. Sci. Lett., 126, 91-108, 1994.

Berger, A.: Long-term variations of daily insolation and Quaternary Climatic Changes, J. Atmos. Sci., 35(12), 2362-2367, 1978.

Bintanja, R., van de Wal, R. S. W., and Oerlemans, J.: Modelled atmospheric temperatures and global sea level over the past million years, Nature, 437, 125-128, 2005.

Bintanja, R., van de Wal, R. S. W., and Oerlemans, J.: Global ice volume variations through the last glacial cycle simulated by a 3-D ice-dynamical model, Quatern. Int., 95-96, 11-23, 2002.

Braconnot, P., Otto-Bliesner, B., Harrison, S., Joussaume, S., Peterschmitt, J.-Y., Abe-Ouchi, A., Crucifix, M., Driesschaert, E., Fichefet, T., Hewitt, C. D., Kageyama, M., Kitoh, A., Laîné, A., Loutre, M.-F., Marti, O., Merkel, U., Ramstein, G., Valdes, P., Weber, S. L., Yu, Y., and Zhao, Y.: Results of PMIP2 coupled simulations of the Mid-Holocene and Last Glacial Maximum Part 1: experiments and large-scale features, Clim. Past, 3, 261277, 2007, http://www.clim-past.net/3/261/2007/.

Brovkin, V., Ganapolski, A., and Svirezhev, Y.: A continuous climate-vegetation classification for use in climate-biosphere studies, Ecol. Modell., 101, 251-261, 1997.

Chen, F. H., Bloemendal, J., Zhang, P. Z., and Liu, G. X.: An 800 ky proxy record of climate from lake sediments of the Zoige Basin, eastern Tibetan Plateau, Palaeogeogr. Palaeocl., 151, 307-320, 1999.

Clark, P. U. and Mix, A. C. (Eds.): Ice sheets and sea level of the last glacial maximum, Quaternary Sci. Rev., 21(1-3), 1-454, 2002.

Clark, P. U., Clague, J. J., Curry, B. B., Dreimanis, A., Hicock, S. R., Miller, G. H., Berger, G. W., Eyles, N., Lamothe, M., Miller, B. B., Mott, R. J., Oldale, R. N., Stea, R. R., Szabo, J. P., Thorleifson, L. H., and Vincent, J.-S.: Initiation andd evelopment of the Laurentide and Cordilleran ice sheets following the last interglaciation, Quaternary Sci. Rev., 12, 79-114, 1993.

Driesschaert, E., Fichefet, T., Goosse, H., Huybrechts, P., Janssens, I., Mouchet, A., Munhoven, G., Brovkin, V., and Weber, S. L.: Modeling the influence of Greenland ice sheet melting on the Atlantic meridional overturning circulation during the next millennia, Geophys. Res. Lett., 34, L10707, doi:10.1029/2007GL029516, 2007.

Duplessy, J. C., Roche, D. M., and Kageyama, M.: The Deep Ocean During the Last Interglacial Period, Science, 316, 89-91, 2007.

EPICA community members: Eight glacial cycles from an Antarctic ice core, Nature, 429, 623-628, 2004.

Gingele, F. X. and Schmieder, F.: Anomalous South Atlantic lithologies confirm global scale of unusual mid-Pleistocene climate excursion, Earth Planet. Sci. Lett., 186, 93-101, 2001.

Goosse, H. and Fichefet, T.: Importance of ice-ocean interactions for the global ocean circulation: a model study, J. Geophys. Res., 104(C10), 23 337-23 355, 1999.

Grose, W. L. and Hoskins, B. J.: On the Influence of Orography on Large-Scale Atmospheric Flow, J. Atmos. Sci., 36, 223-234, 1979.

Guo, Z. T., Liu, T. S., Fedoroff, N., Wei, L. Y., Ding, Z. L., Wu, N. Q., Lü, H. Y., Jiang, W. Y., and An, Z. S.: Climate extremes in Loess of China coupled with the strength of Deep-Water Forma- tion in the North Atlantic, Global Planet. Change, 18, 113-128, 1998.

Harris, S. E. and Mix, A. C.: Pleistocene precipitation Balance in the Amazon Basin recorded in deep sea sediments, Quaternary Res., 51, 14-26, 1999.

Holton, J. R.: An introduction to dynamic meteorology, Academic Press, New York, 391 pp., 1979.

Hoskins, B. J. and Karoly, D. J.: The steady linear response of a spherical atmosphere to thermal and orographic forcing, J. Atmos. Sci., 38, 1179-1196, 1981.

Hughes, T. J., Denton, G. H., Andersen, B. G., Schilling, D. H., Fastook, J. L., and Lingle, C. S.: The last great ice sheets: A global view, in: The last great ice sheets, edited by: Denton, G. H. and Hughes, T. J., J. Wiley \& Sons, New York, 263-317, 1981.

Imbrie, J., Hays, J. D., Martinson, D. G., McIntyre, A., Mix, A. C., Morley, J. J., Pisias, N. G., Prell, W. L., and Shackleton, N. J.: The orbital theory of Pleistocene climate: support from a revised chronology of the marine $\delta^{18} \mathrm{O}$ record, in: Milankovitch and Climate, Part 1, edited by: Berger, A. L., Imbrie, J., Hays, J., et al., D. Reidel Pub. Co., 269-305, 1984.

IPCC-Group I: Climate Change 2007: the Physical Science Basis, Summary for Policymakers. Contribution of Working Group I to the Fourth Assessment Report of IPCC, IPCC secretariat, C/O WMO, Geneva, February, 2007.

Joussaume, S., Taylor, K. E., Braconnot, P., Mitchell, J. F. B., Kutzbach, J. E., Harrison, S. P., Prentice, I. C., Broccoli, A. J., Abe-Ouchi, A., Bartlein, P. J., Bonfils, C., Dong, B., Guiot, J., Herterich, K., Hewitt, C. D., Jolly, D., Kim, J. W., Kislov, A., Kitoh, A., Loutre, M. F., Masson, V., McAvaney, B., McFarlane, N., de Noblet, N., Peltier, W. R., Peterschmitt, J. Y., Pollard, D., Rind, D., Royer, J. F., Schlesinger, M. E., Syktus, J., Thompson, S., Valdes, P., Vettorett, G., Webb, R. S., and Wyputta, U.: Monsoon changes for 6000 years ago: Results of 18 simulations from the Paleoclimate Modeling Intercomparison Project (PMIP), Geophys. Res. Lett., 26, 859-862, 1999.

Jouzel, J., Masson-Delmotte, V., Cattani, O., Dreyfus, G., Falourd, S., Hoffmann, G., Minster, B., Nouet, J., Barnola, J. M., Chappellaz, J., Fischer, H., Gallet, J. C., Johnsen, S., Leuenberger, M., Loulergue, L., Luethi, D., Oerter, H., Parrenin, F., Raisbeck, G., Raynaud, D., Schilt, A., Schwander, J., Selmo, E., Souchez, R., Spahni, R., Stauffer, B., Steffensen, J. P., Stenni, B., Stocker, T. F., Tison, J. L., Werner, M., and Wolff, E. W.: Orbital and Millennial Antarctic Climate Variability over the Past 800,000 Years, Science, 317, 793-796, 2007.

Kukla, G., An Z. S., Melice, J. L., Gavin, J., and Xiao, J. L.: Magnetic susceptibility record of Chinese Loess, Trans. R. Soc. Edinb. Earth Sci., 81, 263-288, 1990.

Kutzbach, E. J. and Guetter, P. J.: The sensitivity of monsoon climates to orbital parameter changes for 9000 years BP: experiments with the NCAR general circulation model, in: Milankovitch and Climate, Part 2, edited by: Berger, A. L., Imbrie, J., Hays, J., et al., D. Reidel Pub. Co., 801-820, 1984.

Lambeck, K., Esat, T. M., and Potter, E. K.: Links between climate and sea levels for the past three million years, Nature, 419, 199206, 2002.

Lisiecki, L. E. and Raymo, M. E.: A Pliocene-Pleistocene stack of 57 globally distributed benthic delta $\delta^{18} \mathrm{O}$ records, Paleoceanography, 20(1), PA1003; doi:10.1029/2004PA001071, 2005. 
Masson, V., Braconnot, P., Jouzel, J., de Noblet, N., Cheddadi, R., and Marchal, O.: Simulation of intense monsoons under glacial conditions, Geophys. Res. Lett., 27, 1747-1750, 2000.

Ohgaito, R. and Abe-Ouchi, A.: The role of ocean thermodynamics and dynamics in Asian summer monsoon changes during the mid-Holocene, Clim. Dynam., 29, 39-50, 2007.

Opsteegh, J. D., Haarsma, R. J., Selten, F. M., and Kattenberg, A.: ECBILT: A dynamic alternative to mixed boundary conditions in ocean models, Tellus, 50A, 348-367, 1998.

Paterson, W. S. B.: The Physics of Glaciers, Pergamon, Tarrytown, N.Y., 1984.

Peltier, W. R.: "Implicit ice" in the global theory of glacial isostatic adjustment, Geophys. Res. Lett., 25(21), 3955-3958, 1998.

Peltier, W. R.: Ice age paleotopography, Science, 265, 195-201, 1994.

Peltier, W. R.: Global glacial isostasy and the surface of the ice-age Earth: the ICE-5G (VM2) model and GRACE, Ann. Rev. Earth Planet Sci., 32, 111-149, 2004.

Prell, W. L. and Kutzbach, J. E.: Monsoon variability over the past 150,000 years, J. Geophys. Res., 92, 8411-8425, 1987.

Prokopenko, A. A., Williams, D. F., Kuzmin, M. L., Karabanov, E. B., Khursevich, G., and Peck, J. A.: Muted climate variations in continental Siberia during the mid-Pleistocene epoch, Nature, 418, 65-68, 2002.

Renssen, H., Goosse, H., and Fichefet, T.: Modeling the effect of freshwater pulses on the early Holocene climate: The influence of high-frequency climate variability, Paleoceanography, 17(2), 1020, doi:10.1029/2001PA000649, 2002.

Roche, D. M., Dokken, T. M., Goosse, H., Renssen, H., and Weber, S. L.: Climate of the last glacial maximum: sensitivity studies and model-data comparison with the LOVECLIM coupled model, Clim. Past, 3, 205-224, 2007, http://www.clim-past.net/3/205/2007/.

Rossignol-Strick, M., Paterne, M., Bassinot, F. C., Emeis, K.-C., and De Lange, G. J.: An unusual mid-Pleistocene monsoon period over Africa and Asia, Nature, 392, 269-272, 1998.

Shackleton, N. J.: The 100,000-year Ice-Age Cycle identified and found to lag temperature, carbon dioxide and orbital eccentricity, Science, 289, 1897-1902, 2000.
Siegenthaler, U., Stocker, T. F., Monnin, E., Lüthi, D., Schwander, J., Stauffer, B., Raynaud, D., Barnola, J.-M., Ficher, H., MassonDelmott, V. and Jouzel, J.: Stable carbon cycle-climate relationship during the late Pleistocene, Science, 310, 1313-1317, 2005.

Schmieder, F., Dobeneck, T., and Bleil, U.: The Mid-Pleistocene climate transition as documented in the deep South Atlantic Ocean: initiation, interim state and terminal event, Earth Planet. Sci. Lett., 179, 539-549, 2000.

Spahni, R., Chappellaz, J., Stocker, T. F., Loulergue, L., Hausammann, G., Kawamura, K., Fluckiger, J., Schwander, J., Raynaud, D., Masson-Delmotte, V., and Jouzel, J.: Atmospheric Methane and Nitrous Oxide of the Late Pleistocene from Antarctic Ice Cores, Science, 310, 1317-1321, 2005.

Tiedemann, R., Sarntheim, M., and Shackleton, N. J.: Astronomic timescale for the Pliocene Atlantic $\delta^{18} \mathrm{O}$ and dust flux records of Ocean Drilling Program site 659, Paleoceanography, 9, 619-638, 1994.

Timmermann A., Justino Barbosa, F., Jin, F. F., and Goosse, H.: Surface temperature control in the North Pacific during the last glacial maximum, Clim. Dynam., 23, 353-370, 2004.

Wang, B., Clemens, S. C., and Liu, P.: Contrasting the Indian and East Asian monsoons: implications on geologic timescales, Mar. Geol., 201, 5-21, 2003.

Wang, P., Tian, J., Cheng, X., Liu, C., and Xu, J.: Major Pleistocene stages in a carbon perspective: The South China Sea record and its global comparison, Paleoceanography, 19, PA4005, doi:10.1029/2003PA000991, 2004.

Yanase, W. and Abe-Ouchi, A.: The LGM surface climate and atmospheric circulation over East Asia and the North Pacific in the PMIP2 coupled model simulations, Clim. Past, 3, 439-451, 2007, http://www.clim-past.net/3/439/2007/.

Yin, Q. Z. and Guo, Z. T.: Mid-Pleistocene vermiculated red soils in southern China as an indication of unusually strengthened East Asian monsoon, Chinese Sci. Bull., 51(2), 213-220, 2006.

Yin, Q. Z. and Guo, Z. T.: Strong summer monsoon during the cool MIS-13, Clim. Past, 4, 29-34, 2008, http://www.clim-past.net/4/29/2008/ 